\title{
The Short Stint of a Coordinator: National Security Adviser H. R. McMaster in the Trump Administration
}

Mikael Blomdahl

\section{(2) OpenEdition Journals}

Electronic version

URL: https://journals.openedition.org/ejas/17099

DOI: 10.4000/ejas.17099

ISSN: 1991-9336

Publisher

European Association for American Studies

Electronic reference

Mikael Blomdahl, "The Short Stint of a Coordinator: National Security Adviser H. R. McMaster in the Trump Administration", European journal of American studies [Online], 16-2 | 2021, Online since 14 July 2021, connection on 17 October 2022. URL: http://journals.openedition.org/ejas/17099 ; DOI: https:// doi.org/10.4000/ejas. 17099

This text was automatically generated on 17 October 2022.

\section{(c) (1) (9)}

Creative Commons - Attribution-NonCommercial 4.0 International - CC BY-NC 4.0 https://creativecommons.org/licenses/by-nc/4.0/ 


\title{
The Short Stint of a Coordinator: National Security Adviser H. R. McMaster in the Trump Administration
}

\author{
Mikael Blomdahl
}

\section{Introduction}

1 On February 20, 2017, President Donald Trump announced that Lieutenant General H. R. McMaster had agreed to serve as his second assistant to the president for national security affairs (APNSA) to fill the vacancy left by the resignation of Michael Flynn. McMaster earned a Ph.D. in American history from the University of North Carolina. His Ph.D. thesis was critical of American strategy and military leadership during the Vietnam War and served as the basis for his book Dereliction of Duty, which is widely read in the United States military. ${ }^{1}$ McMaster was highly regarded for his battlefield leadership during the Persian Gulf War and later in the Iraq War. He became a top counterinsurgency advisor to General David Petraeus and also served as the Deputy to the Commander for Planning of the International Security Assistance Force in Afghanistan (ISAF). As a combat veteran in Iraq and Afghanistan, he was a well-respected defense intellectual. This appointment was widely welcomed by commentators in Washington after the first person at the post, Michael Flynn's initial period of instability. McMaster strived to restructure the National Security Council (NSC) but was increasingly faced with White House criticism of his performance as NSC advisor as well as numerous reports that his days in the post were numbered. ${ }^{2}$ Indeed, on March 22, 2018, McMaster was forced out as APNSA after sustaining the indignation of conservatives for months and disagreeing with Trump on key foreign policy strategies. $^{3}$

2 The APNSA is one of the most important individual members in US foreign policymaking. Almost every APNSA since McGeorge Bundy, during the 1960s, merged as 
a principal player in foreign policy making. Over the years, the organization of the National Security Council (NSC) has become less like a staff and more like an operating agency. The NSC staff has expanded from a small group of less than fifteen people in the early 1960s to what was, during the Obama administration, a fully installed, agencylike organization of more than two hundred people. In some administrations, the APNSA has become one of the key principals in foreign policy making, yielding significant power, at times even more than cabinet secretaries. This rise in prestige and influence has also created a discussion surrounding the fact that the position is not confirmed by Congress. Thus, contrasting the jobs of cabinet counterparts, the position as APNSA is neither rooted in law nor accountable to Congress. So, as the point person on foreign policy, the APNSA serves at the pleasure of the president. Besides, the public obligations of the APNSA are far more limited than those of, for example, the secretary of state, who is the president's principal foreign policy spokesperson both at home and abroad. ${ }^{4}$

3 Previous studies have examined the role of the APNSA in order to develop a greater understanding of the U.S. foreign policy decision-making process. ${ }^{5}$ Their work show that the NSC staff's power and size have grown tremendously over time and that this expansion has resulted in its members, especially the APNSA, having greater responsibility. Additional studies have also tried to categorize different APNSAs and determine what role they played in their respective administrations. ${ }^{6}$ Various case studies have also applied typologies and models of NSC advisor roles to individual APNSAs. ${ }^{7}$ Thus, quite a number of scholars have analyzed the characteristics and possible roles of advisers. ${ }^{8}$ However, H. R. McMaster's role as APNSA is essentially not evaluated from a formal political science framework. Against this background, this article puts focus on the following basic research question. What role did H. R. McMaster play as APNSA in the Trump administration?

4 This article asserts that McMaster's relatively short tenure as APNSA offers scholars of U.S. foreign policy with a valuable opportunity to continue the study and further contribute to this body of scholarship of one of the more prominent and influential positions within the U.S. foreign policy making community. Drawing on the APNSA typology literature, the central argument of this article is that McMaster started out in the role as a coordinator of the NSC. Coordinators have high implementation responsibility and low policy-making responsibility, and this combination of responsibility levels results in coordinators focusing largely on managing the interagency process. In this role, the APNSA do not rise to the level of a personal foreign policy advisor to the president or initiator of particular policies. ${ }^{9}$ McMaster did manage the day-to-day operations of the NSC as well as the coordination of the interagency process, but he never developed a close advisory relationship with President Trump. As a result his power and influence in the role of coordinator with time became limited.

5 Moreover, an assessment of McMaster role as APNSA is particularly important because of President Trump's unconventional management style. ${ }^{10}$ At the start, McMaster focused on creating a textbook national security process. He worked issues through an interagency process consisting of working-, deputy-, and cabinet-level committees bringing all relevant views and expertise into the process. ${ }^{11}$ Yet, in the White House, Trump eschewed formal process and expertise and instead relied on his impulses. Hence, President Trump's tenure in the White House reveals several unique decision- 
making dynamics that break with traditional approaches of presidential management and an opportunity to reassess the traditional typology of the APNSA. ${ }^{12}$ Based on this, this study will put the findings of the analysis of the APNSA typology in the context of traditional presidential management literature at the end of the article.

6 Consequently, the president's chief White House adviser for national security affairs, must be carefully examined to achieve a comprehensive and descriptively accurate conception of the US foreign policy making process. ${ }^{13}$ Because the Trump administration recently left office, any records to answer these questions conclusively will be classified. The sources available are public documents such as public speeches, press conferences, press releases, and memoirs. Based on this, the study design in this article should be considered "exploratory". ${ }^{14}$

7 This article proceeds as follows. The next section identifies the key elements and characteristics of the APNSA analytical categories as well as describes how the typology will be applied to McMaster. After that McMaster's role is evaluated through primary and secondary sources. according to the characteristics of the APNSA typology. The study examines four important aspects of McMaster's tenure: how he managed the NSC, two of the Trump administration's most important first and second-year foreign policy decisions: the Joint Comprehensive Plan of Action (JCPOA), McMaster's role in the decision to send more troops to Afghanistan, and finally McMaster's relationship with President Trump.

8 The two specific cases studies of JCPOA and the decision to send more troops to Afghanistan are argued to provide a suitable test of the APNSA role employed by McMaster. They are designed to understand the general dynamics involved in the administration's decision-making process, as well as to identify the presence or absence of the characteristics of the different APNSA roles. They are both high-profile security issues, which ensures that the president will be more involved and there is the greater probability that they will be attentive to the structure of the decision-making process. The cases vary in terms of the decision-making influence of the APNSA and resulted in changes to existing U.S. policy. Although the cases also do vary in the types of issues negotiated, the focus on security interests permits control over of other forms of variability between them.

9 Finally, the study summarizes the primary argument of the study, relate them to presidential management literature, and discusses the need for further research.

\section{A Typology of APNSA roles}

10 Since President John F. Kennedy named McGeorge Bundy to the position of APNSA in 1961, presidents have engaged national security advisors to serve two main functions. The first is process management, which includes setting up an orderly flow of information to the White house in a manner in harmony with the president's management style, bringing all points of view and the needed expertise to bear when formulating decisions, engaging senior officials so they and the president know one another's views, communicating the president's decisions to the broader government, and ensuring these decisions are implemented in the way the president intended. ${ }^{15}$

11 The second function is to provide the president with their policy advice. ${ }^{16}$ Beyond acting as process managers, all APNSAs come to the position with points of view on policy, and because these advisors sit closest to the Oval Office, all presidents have wanted to get 
their advice on important policy issues. According to Daalder and Destler, the most successful national security advisors have performed in both functions, but with an emphasis on process management. ${ }^{17}$

Kevin Mulcahy and F Kendrick created a typology of the APNSA's roles, based on the interaction of two central variables, grading each of them from low to high. ${ }^{18}$ The first variable associated with the typology, policy-making responsibility, is defined as the formulation of new initiatives in foreign affairs that results from a close association with the president. ${ }^{19}$ The second variable, implementation responsibility, refers to the APNSA's involvement in hands-on direction of departmental programs as presidential surrogate.$^{20}$ Policy-making responsibility is measured through examining the type of personal advisory relationship McMaster established with Trump and whether the president directed him to oversee the development of policy initiatives. Implementation responsibility, conversely, is assessed through examining whether McMaster served as a presidential surrogate and directly managed the implementation of presidential policies, or whether other actors in the administration assumed this role. This study employs these variables to develop a typology of four roles that an APNSA traditionally perform within an administration..$^{21}$ This typology comes up with four principal APNSA roles: administrator, coordinator, counselor and agent.

The role of an administrator involves both low policymaking and implementation responsibility. Administrators are effectively the day-to-day manager of the NSC and assist in briefing the president on the international situation. ${ }^{22}$ Administrators do not enjoy a close personal advisory relationship with the president, nor are they responsible for developing and pursuing foreign policy initiatives.

Coordinators have high implementation responsibility and low policy-making responsibility. This combination of responsibility levels results in coordinators focusing largely on managing the interagency process. These advisors are more powerful and involved than administrators, but they do not rise to the level of a personal foreign policy advisor to the president or initiator of particular policies. ${ }^{23}$

The role of counselor builds upon the previous two roles in its much higher degree of policy-making responsibility. Counselors essentially serve as the personal foreign policy advisor to the president. These APNSA attain the highest level of personal interaction, access, and comfort with the president and are often seen as indispensable. Counselors also depart from administrators and coordinators in that they often are personal advocates for a particular policy option..$^{24}$

The fourth role of an APNSA is as agent. Agents are extraordinarily powerful and influential foreign policy actors who position themselves at the center of foreign policy making. Agents dominate the interagency process and combine the administrator, coordinator, and counselor roles in a mixture that rivals the State Department for establishing and controlling foreign policy. Agents enjoy close personal advisory relationships with the president, and centralize foreign policy making in the White House. ${ }^{25}$ 
Implementation Responsibility

Policy-Making Responsibility

\begin{tabular}{|l|l|l|}
\hline & Low & High \\
\hline Low & Administrator & Coordinator \\
\hline High & Counselor & Agent \\
\hline
\end{tabular}

Figure 1: APNSA Activism Variables ${ }^{26}$

This typology, then, provides scholars with an applicable model with which to analyze the role of specific APNSAs. This study employs the two variables of policymaking and implementation responsibilities to determine what role McMaster played as APNSA. Policy-making responsibility is evaluated through examining the type of personal advisory relationship McMaster formed with President Trump and whether the president ordered McMaster to manage the development of policy initiatives. Implementation responsibility, in the same way, is evaluated through examining whether McMaster served as a presidential surrogate and directly managed the implementation of presidential policies, or whether other actors in the administration assumed this role. ${ }^{27}$

\section{Lieutenant General H. R. McMaster. Management of the NSC}

On February 20, 2017, President Trump announced that McMaster had agreed to serve as APNSA. McMaster arrived at the White House after the ouster of his predecessor, Michael Flynn, but with few ties to the president or his administration. McMaster strived to reorganize the NSC after Flynn's tumultuous tenure as the first APNSA. Among other things, he replaced several members of the NSC that Flynn had brought on and modified its organizational structure. ${ }^{28}$ One of the new APNSAs significative achievements was National Security Presidential Memorandum-4 (NSPM-4), issued on April 4, 2017.29 In this document he made changes to the NSC and consolidated the APNSAs authority in managing the NSC as well as the reinstated Homeland Security Council (HSC). Specifically, NSPM-4 reinforced McMaster's role by establishing that the APNSA was responsible for determining the agenda for the NSC and HSC. ${ }^{30}$

Another important change was White House political strategist Steve Bannon's removal as a member of the NSC Principals Committee. Based on this, he ended up with a freer hand in controlling NSC staff and, according to some commentators, McMaster's efforts represented a victory in reviving the so-called "Scowcroft model" of the APNSA. In this model, the APNSA avoids pushing his own policy agenda in favor of serving as a referee for proposals put forth by NSC staff and the career professionals from the national security and foreign policy agencies, that also participate in high-level meetings. ${ }^{31} \mathrm{In}$ an interview with the BBC, McMaster announced that he was determined to be an honest broker who would coordinate policy deliberations among government agencies and 
then present potential courses of action to the President. ${ }^{32}$ Thus, from the start, McMaster wanted to make it clear that he oversaw the NSC staff, and clearly asserted his authority as APNSA along more traditional lines. In the NSC memorandum, McMaster, as the APNSA, assume the role of coordinator. He established the day-to-day operating guidelines and procedures of the NSC and detailed his expectations for the functions of the body. ${ }^{33}$

However, the new APNSA early became the subject of leaks and negative commentary by foreign policy nationalists complaining that he was blocking the Trump so-called "America-first" agenda. According to these reports, McMaster had been in the crosshairs of the nationalist wing close to Trump since the start of his tenure. Critics viewed him as "too representative of establishment, 'globalist' foreign policy", particularly when it came to Israel and Iran. ${ }^{34}$

21 Moreover, President, Trump's tendency to informality and loose organizational structures led him to assign overlapping responsibilities among his advisors, generating some confusion regarding who speaks for the administration on foreign policy. ${ }^{35}$ For example, despite the formal national security structure, Trump appointed his son-in-law, Jared Kushner, as the White House senior advisor responsible for several important international issues, such as promoting Middle East peace, and as liaison to Mexico, China, and the Arab states. ${ }^{36}$ While Kushner was supposed to make McMaster and the NSC staff aware of his foreign contacts, McMaster became aware of that Kushner had contacts with foreign officials that he did not coordinate through the NSC or officially reported ${ }^{37}$ In fact, McMaster was alarmed to find out about Kushner's ranging foreign-policy involvement: "You mean I've got somebody running a significant part of foreign policy who doesn't report into my structure?" ${ }^{38}$ Furthermore, apart from Trump's proclivity for informality and loose organizational structures, the president's negligent involvement in White House affairs also allowed uncertainty to foster as to who had effective authority on defining foreign policy. ${ }^{39}$

McMaster's management of the NSC is one example of how he started out in the role of APNSA coordinator. The transition had failed to put in place an effective national security system. McMaster quickly remedied this and embraced standard order: internal dynamics changed, and a new team was eventually brought on board. McMaster focused on creating a textbook national security process. He worked issues through an interagency process consisting of working-, deputy-, and cabinet-level committees bringing all relevant views and expertise into the process, and decision papers prepared for presidential review. In describing McMaster's accomplishments, numerous officials also pointed to the relatively moderate language of the National Security Strategy (NSS) document, released on December 18, 2017.40

However, sound structures and systems are necessary, but not sufficient. Who occupies key positions and what skills and expertise they bring to the job are naturally also important. According to account in The New Yorker staff members argued that: "We built this process that was incredibly effective, and McMaster "would constantly pull people back into process." It had the appearance of something that former APNSAs Stephen Hadley, Condoleezza Rice or Susan Rice would acknowledge, "but it's not getting the work done." ${ }^{41}$

Over time, it became clear that Trump was more comfortable with informal Oval office meetings and often reached out to interlocutors on Capitol Hill and friends outside of the administration to assess their reactions, and then make his decisions. According to 
another former staff member there were two parallel tracks: "there's the interagency process, and then Trump makes a decision". But there is often no suggestion that he is making decisions with reference to that process: "It's two ships passing in the night". ${ }^{42}$ McMaster never caught on and therefore failed to adapt the process to serve this particular president, as all advisors need to do. ${ }^{43}$

\section{The NSC and the Interagency Process: The Decision to Send More Troops to Afghanistan in 2017}

During Trump's first six months in office, the president advocated pulling out of Afghanistan while the military pushed for more troops. However, during McMaster's tenure as APNSA, he and defense secretary Jim Mattis managed to shape the president 's decision-making. Trump ultimately endorsed Mattis' recommendation to deploy more than 3,000 U.S. reinforcements and embrace an expanded military advisory strategy. In an August 2017 speech announcing his decision, Trump alluded to how established foreign policy figures in his administration had changed his mind. ${ }^{44}$

Hence, one of the issues McMaster would try to show his engagement in was U.S. strategy towards Afghanistan, where he had served in 2010 and 2011. He was "determined to get the U.S. president options to achieve sustainable security in Afghanistan (...)" ${ }^{45}$ McMaster had conducting a major policy review of America's long and failed war in Afghanistan his personal mission. He pushed hard to get a new strategy that would include the relatively modest troop increases and a commitment to another four-year timeline approved in advance of Trump's May summit with NATO allies in May 2017. Thus, before becoming President, Trump had criticized the war in Afghanistan, and once he was in office, he expressed frustration that the U.S. was still involved in the long conflict. McMaster visited Afghanistan, Pakistan, and India in April, shortly after he became APNSA and launched a strategy review of American policy in South Asia upon his return. ${ }^{46}$

In meetings between President Trump and McMaster during the spring of 2017, Trump wanted to know why the U.S. military was not winning in Afghanistan, and why the U.S. was still stuck there. ${ }^{47}$ At the time, these two questions defined a contentious debate over whether to send more U.S. troops to Afghanistan to halt two years of Taliban gains. The strategy Trump inherited had been defined by the Obama administration's focus on withdrawing American forces and ending the war. According to McMaster, one key to a better result was an open-ended commitment that would demonstrate American resolve and compel the Taliban to agree to peace talks. In this way, McMaster's version of "America first" in Afghanistan meant negotiating from a position of strength..$^{48}$ One of his biggest challenges, however, was holding the attention of President since he had little time for in-depth briefings on Afghanistan's history or its civil war. Another problem was overcoming Trump's skepticism that winning in Afghanistan was even possible..$^{49}$ So, the APNSA wanted something that would appeal to the president's instincts as a promoter and he, therefore, showed pictures of Kabul from 2005 and 2015 in order to show how businesses and traffic had returned to the once- deserted region. The goal was to give the president the idea that Afghanistan was not a hopeless place, but such briefings did not change Trump's position. ${ }^{50}$ Afghanistan strategy, and in at least one instance McMaster lost his temper, shouting: 
"You're a liar". Bannon pushed for a withdrawal of troops and called McMaster a "globalist" who was all too willing to commit troops to conflicts in which America had little strategic interest. ${ }^{51}$

At McMaster's advising, Trump had, early in summer 2017, signed an order giving the Pentagon the authority to send as many as 3,900 more troops requested by commanders to Afghanistan without seeking separate approval. However, Mattis was concerned about the absence of an approved strategy and by Trump's doubts about the war and did not authorize the the deployment of forces. At a meeting in June, the president complained that the United States was not winning in Afghanistan, suggested firing the current commander and questioned whether sending more troops to the country would be stupidity. ${ }^{52}$

In mid-July 2017, Trump's senior Cabinet officials and top national security advisers met for a contentious meeting to finally agree on a new strategy for America's longest war. After months of quarreling, they would ask him for a modest troop increase and a more intense commitment to the struggle in Afghanistan. During the session of the NSC Principals Committee, however, Trump refused to sign off on the plan they approved, instead sending it back to the national security team demanding more work. ${ }^{53}$ According to various accounts, the president's reluctance was also a striking vote of noconfidence in the APNSA. Instead, secretary of state Rex Tillerson teamed up with secretary of defense Jim Mattis to block McMaster's initial version, which they believed Trump and political advisers such as Bannon, would not support without clearer markers of success. After the initial rejection of McMaster, the review was broadened to cover policy toward Afghanistan's neighbors India and Pakistan as well. At the time, reports argued that this was yet another indication that McMaster was increasingly an APNSA out of sync with the president. On Afghanistan and other key policy issues, McMaster recommended a more stay-the-course approach, only to find pushback from the president. ${ }^{54}$

31 The fight over the Afghanistan strategy pointed to a larger problem with the relationship between McMaster's NSC and the president. During his first six-months on the job, McMaster raised morale among the career staffers, who described him as open and accessible. He had also put in place a rigorous and structured process that integrated the views of agencies across the government. With the lack of new policies, however, the administration had worked in small stages to give U.S. commanders in Afghanistan more latitude to increase the pace of military operations. ${ }^{55}$ Hence, potentially divisive questions about the United States' long-term goals and military presence in the region remained unresolved in the Afghanistan review.

In August, however, Trump made the decision to increase troop levels in Afghanistan after a meeting with his military advisors. At a Camp David meeting, he was presented with three options: scale back to a skeletal presence; deploy only a robust counterterrorism operation headed by Joint Special Operations Command and the CIA; or increase troop levels by 4,000 to 5,000 while at the same time increasing counterterrorism operations. Trump selected the the third option. ${ }^{56}$ In this way, Trump`s shift signaled the influence of McMaster and Mattis, as well as chief of staff John F. Kelly, and reflected the waning influence of the faction led by Bannon. According to McMaster, the U.S. had now "articulated a realistic, sustainable strategy". ${ }^{57}$

33 In the review process, McMaster facilitated policymaking and was responsible for defining policy options for the president. While many had complained that McMaster 
held too many meetings, he worked in the role as coordinator following a traditional process where the president is presented a range of options on key issues, along with a list of risks associated with each option. On several occasions he employed an orderly deliberation process and the administration discussed the U.S. strategy of South Asia for months as opposing parties tried to sway the president toward their policy prescriptions..$^{58}$ Thus, despite his campaign rhetoric, Trump sided with McMaster and Mattis and decided to raise the number of U.S. troops in Afghanistan by 3900 . McMaster, along with Mattis, and Kelly were able to convince the president that a U.S. withdrawal would have negative consequences throughout the region. Thus, in the meetings they succeeded in convincing the president that an open-ended commitment would demonstrate American resolve and compel the Taliban to agree to peace talks. In this case, McMaster, as an APNSA coordinator, was more involved and acted more powerful than administrators, but as noted above, he did not rise to the level of a personal foreign policy advisor to the president or initiator of particular policies. In this case, the president sided with his national security team because this decision allowed him to "be seen as a strong and decisive leader". ${ }^{9}$

\section{The NSC and the Interagency Process: The Joint Comprehensive Plan of Action}

In July 2015, the United States, France, Great Britain, Germany, China, Russia, the European Union High Representative for Foreign Affairs and Security Policy, and Iran signed the Joint Comprehensive Plan of Action (JCPOA). The agreement established that Iran would curtail its nuclear program in exchange for the lifting of many of the sanctions imposed by the United Nations (UN). However, during his election campaign, Trump criticized the agreement and promised to dismantle it once in office. ${ }^{60}$ Even with opposition to the agreement in Congress, and the submission of several joint resolutions of disapproval in the Senate and the House, no congressional resolution on the JCPOA passed. ${ }^{61}$ APNSA McMaster belonged to those who wanted to maintain the agreement worked to find a compromise solution that would accommodate Trump's instinctive opposition to the deal without ending it completely.

Once in office, the Trump administration rapidly imposed sanctions on Iran as a response to a ballistic missile test and alleged support of terrorism in the Middle East. However, despite the more aggressive rhetoric, the administration reluctantly confirmed in April 2017 that Iran was fulfilling the obligations set out in the agreement. In the meantime, the White House began conducting an evaluation of the provisions of the JCPOA. ${ }^{62}$ While there was a broad consensus in the administration that Iran was involved in prohibited activities not covered by the agreement, officials did split internally between those who supported the JCPOA and those who advocated decertifying the JCPOA. At the time, McMaster along with Tillerson and Mattis argued that while Iran should be criticized for its aggressive actions in the Middle East, the JCPOA should not be associated to these activities. ${ }^{63}$

In a meeting on July 17, 2017, Trump demanded more options from his advisors and promised not to certify the agreement again in the future. ${ }^{64}$ The same day, however, Trump again reluctantly certified to Congress that Iran continued to meet the conditions stipulated in the agreement. By this time, however, Trump had grown increasingly frustrated with having to renege on one of his signature foreign policy 
campaign pledges. ${ }^{65}$ The president was irritated by the arguments of McMaster, Tillerson and Mattis that the landmark 2015 deal, while flawed, offered stability and other benefits. He did not want to certify to Congress that the agreement remained in US national security interest and that Iran was meeting its obligations. ${ }^{66}$ Without formal decision-making structures and processes in place and mindful of Trump's dissatisfaction with the existing choices, advisors again competed in trying to influence the president on the policy toward Iran. McMaster and his NSC team sought to find a compromise solution that would accommodate Trump's instinctive opposition to the JCPOA without terminating it completely ${ }^{67}$ Facing the opposition from his national security team, Trump personally involved Senator Tom Cotton (R-Ar) in the internal debate to make the case for decertification. Cotton had been one of the fiercest Republican opponents of the Iran deal in Congress. ${ }^{68}$

As deadline for certifying the agreement approached, McMaster, Mattis and Tillerson continued to try to convince the president to maintain the Iran deal. Mattis, and the chairman of the Joint Chiefs of Staff (CJCS), Joseph Dunford sought to compel the president by making their views public. For instance, in early October, they told the Senate Armed Services Committee that they believed that Iran was complying with the conditions stipulated in the agreement. ${ }^{69}$ Nevertheless, Trump had already received the information that supported his views and would not yield. At the time, McMaster had been working closely with Senators Bob Corker (R-Tenn.) and Ben Cardin (D-MD) on an agreement that took away the congressional deadlines on Iran that Trump disliked to prevent him from destroying the Iran deal. This would be a face-saving way for the White House to accept the deal. Accordingly, the national security team, led by McMaster, developed a compromise solution-decertifying the agreement but avoiding the reimposition of congressional sanctions on Iran. ${ }^{70}$ The APNSA planned to curtail new sanctions by assuring members of Congress that the administration would initiate a pressure campaign against Iran, particularly targeting Iranian-backed militias and terrorist groups and their financial networks. ${ }^{71}$ The proposal sought to allow the president to demonstrate contempt for the agreement and show a new level of toughness toward the Iranian regime, without triggering the international chaos, McMaster, Mattis and Tillerson warned would follow from a total withdrawal from the deal. ${ }^{72}$ Thus, the president could fulfill his campaign pledge to decertify the agreement by foisting the decision to reimpose any punitive measures onto Congress.

38 As a result, on October 13, 2017, Trump announced that he would not certify the agreement due to Iran's violation of the treaty by allegedly continuing "to fuel conflict, terror, and turmoil throughout the Middle East and beyond". ${ }^{73}$ Thus, he ignored his national security team's initial recommendations and embraced his "America First" agenda,

The Trump administration delayed the reimposition of sanctions again on January 12 , 2018. Once more, Trump threatened to unilaterally withdraw from the JCPOA unless the terms of the agreement were changed. ${ }^{74}$ For its part, the administration continued to show signs of disorder as Trump continued to threaten the Iranian regime throughout the spring of 2018 and then unexpectedly announcing in late July that he was willing to meet with Iran's leaders without any preconditions. According to McMaster this created a window of opportunity for U.S. allies to demonstrate the viability of staying in the deal while imposing costs on Iran for its destructive behavior. 
However, "(T)hat window closed soon after I departed the White House," on April 9, $2018 .^{75}$

Interpersonal relationships were sometimes unstable, with APNSA McMaster a bit more prone to defer to Trump once he made his presentation of the options. ${ }^{76}$ However, McMaster, Tillerson, and Mattis, as well as Kelly on occasion, sometimes collaborated to forestall actions they viewed as ill advised. McMaster administered the strategy review of the Iran deal and, at times, attempted to impose his personal policy position on the president or other principals at the NSC. He was skeptical of decertifying the agreement and argued in favor of preserving the deal. ${ }^{77}$

McMaster directed a series of NSC meeting from 2017 to April 2018 that considered various options for U.S. policy in relation to the JCPOA and acted as a sort of referee during the often- rancorous debate. ${ }^{78}$ McMaster's direction of the JCPOA underscores how he served in the role of coordinator of the overall interagency process. The APNSA managed the review process and attempted to ensure that the views of the principals were heard and then accurately transmitted, that differing opinions were presented and represented fairly, and that the president was provided with necessary information and options in order to make a final decision. McMaster did play a major role in persuading the president on three occasions, in April, June and October 2017, to continue the deal pending further alterations in its terms. While managing and directing the NSC review process, McMaster allowed other principals such as Mattis, Tillerson and CJCS Dunford, among others, to openly debate the various policy options. The APNSA also developed and defined policy options for consideration. Thus, on three occasions the president's aides, among them McMaster, successfully persuaded him not to not to completely jettison the Iran agreement. ${ }^{79}$

However, on 8 May 2018, when McMaster had left the position as APNSA, the U.S. withdrew from the agreement after President Trumpsigned a Presidential Memorandum ordering the reinstatement of harsher sanctions..$^{80}$ This is an indicator of President Trump's proclivity for removing dissonant voices from the administration and replacing them with actors more supportive of his own views and management.

\section{Working Relationship with the President}

43 One of the biggest challenges that McMaster faced as APNSA was his relationship with the president. McMaster was a newcomer to the tight, loyalty-driven Trump inner circle. The APNSA did not see his role as simply a flexible instrument of Trump's changing will, but, as noted above, more of a traditional APNSA of providing straightforward information and analysis to the president. Reports at the time stated that McMaster had a record of being quite forthright and in his first week on the job, had already shown an independence familiar to past colleagues. ${ }^{81}$ As it turned out, however, McMaster's relationship with Trump proved problematic at times and he never quite connected with the president. McMaster was disciplined and focused but frequently clashed with the President, who loved small talk and wandered from one subject to another. ${ }^{82}$

According to accounts in The Atlantic, the president had privately expressed irritation with McMaster stemming from differences in "personality and style" and Trump was irritated at McMaster's briefing style because he was "gruff and condescending". ${ }^{33}$ The president seemed to resent advice and instruction. McMaster's style and preference for 
order seemed to make him a troubled fit with a president whose style is unstructured, and who has little patience for the details and nuances of complex national security issues. ${ }^{84}$

Already in November 2017, the president and Kelly discussed concerns about McMaster's fitness for the job as APNSA. They decided to keep McMaster in place because removing him would have demanded a search for a third APNSA in a year, and they could not agree on a replacement. This is an indication of how tumultuous McMaster's relationship with the president was. ${ }^{85}$

Moreover, McMaster also had difficulties with Mattis and Tillerson that surpassed standard political competition over power and access. These difficulties centered around the president and over how much to accommodate the demands of the unpredictable and contentious president they had signed up to serve. ${ }^{86}$ Mattis and Tillerson sought to varying degrees to push back against the president while they thought that McMaster had a habit of trying to accommodate the President's demands.

The tensions between McMaster and President Trump became public in February 2018, when the APNSA stated at a security conference in Munich that the evidence of Russian interference in the 2016 presidential election was beyond dispute. The statement drew a rapid rebuke from Trump on Twitter: "General McMaster forgot to say that the results of the 2016 election were not impacted or changed by the Russians and that the only Collusion was between Russia and Crooked H, the DNC and the Dems". ${ }^{87}$ Even given McMaster's efforts at improvement of the NSC, outcomes depended on how the president processed its work and it is clear that Trump was not a standard presidential decision maker. Traditionally, the APNSA physical proximity to the President confers a special power that Cabinet secretaries do not have. Yet, McMaster's daily exposure to Trump did not strengthen his authority but rather weakened it. ${ }^{88}$ McMaster's relationship with President Trump points out that orderly organization can carry an NSC process only so far. What might seem reasonable behavior on the NSC advisor's part in insuring good order can interconnect poorly with presidential expectations.

48 According to presidential management scholars, all presidential administrations develop three simultaneously operating decision-making structures after some time in office ${ }^{89}$ These are an initial formal interagency structure (the theory of cabinet government put into practice) that is designed for inclusivity and diversity; an informal structure in which the senior officials and the president operate within a truncated version of the NSC; and an confidence structure in which the president relies on one or two advisors more than any other. since president learns to trust some advisors more than others. In this structure, the president will implicitly or explicitly arrange his advisors in a hierarchy and there will be a first-among-equals advisor, who has a unique relationship with the president..$^{90}$ The use and interactions between these structures are dependent on the leadership style of the president and will vary from administration to administration. In this context, this analysis illustrates how McMaster was not included in the confident structure and, at during the end of his tenure also largely excluded from the informal structure.

\section{Conclusions}

In many ways H. R. McMaster's tenure as APNSA was in the role of coordinator, diligently presenting options and policy analysis to a president who, however, was 
unwilling to read or listen. What factors, then, contributed to McMaster role as a coordinator of the APNSA?

McMaster focused on creating a textbook national security process. In the beginning McMaster was credited for bringing order to a NSC that was overwhelmed by chaos and sinking morale after the firing of Michael Flynn. The APNSA chaired the Principals Committee meetings. He worked issues through an interagency process consisting of working-, deputy-, and cabinet-level committees bringing all relevant views and expertise into the process. Options were debated and defined, and decision papers prepared for presidential review. In both the evaluated cases, the decision to send more troops to Afghanistan and the JCPOA, Mc Master facilitated policymaking and was responsible for defining policy options for presidential consideration. While many had complained that McMaster held too many meetings, he worked in the role as coordinator following a traditional process where the president is presented a range of options on key issues, along with a list of risks associated with each option. On several occasions he employed an orderly deliberation process.

However, McMaster relationship with President Trump is a useful reminder that orderly organization can carry the NSC process only as far as the president allows. The president can empower the APNSA to serve as a surrogate or spokesperson for foreign policy. In contrast, the president can reduce the APNSA to a foreign policy clerk and NSC functionary. President Trump seemed to have no interest in process. He was more comfortable with informal Oval office meetings and reached often out to interlocutors on Capitol Hill and friends on the outside to test their reactions, and then made his decisions. This had a negative impact on McMaster's management of the NSC and he therefore failed to adapt the process to serve this particular president as all advisors need to do. In this way, the president never allowed McMaster to act as a personal foreign policy advisor. As it became evident, McMaster and President Trump clearly differed on policy, with the APNSA cautioning against ripping up the nuclear deal with Iran without a strategy for what would come next, and tangling with President Trump over the strategy for American forces in Afghanistan. McMaster's never gained the trust or confidence of President Trump and at the end, failed to conform to that of the president. McMaster's lack of a personal political relationship with Trump prior to accepting the APNSA position crippled his ability to serve as a counselor to the president.

Scholars of presidential management strategies suggest that while individual presidents are unique, there is a pattern to the types of management strategies presidents employ. Three conventional management models are usually discussed; formalistic, collegial, and competitive. ${ }^{91}$ In the formalistic model, the president centralizes the advisory system in his White House staff that is responsible for managing the information flow to and from the president. The model emphasizes an orderly, disciplined, and hierarchical decision-making structure with well-defined formal routines and processes for developing and selecting policy proposals and recommendations. The collegial system in contrast, seek to create an inclusive advisory process and emphasizes negotiation and compromise among the multiple advisors. This requires a much more active involvement on the part of the president. In the competitive model, the president purposefully encourages competition among advisors by attributing overlapping assignments and authority to individuals on an ad hoc basis. The president centralizes the decision-making process on himself by having competing 
advisors forced to bring policy problems and advice to him for final resolution. ${ }^{92}$ In this analysis President Trump's management style bear resemblances to the competitive model. As the case studies illustrates, Trump's advisory process promoted competition among his advisors and fostered rivalries among advisors. A question to address in future studies, however, is whether this resulted from a deliberate attempt to implement coherent structures and processes or if it as argued by Luis da Vinha is "the byproduct of Trump's policy detachment and proclivity for making improvised decisions based on his gut feeling". ${ }^{33}$ Despite attempts by McMaster to establish procedures for vetting the information and proposals to the president, Trump routinely circumvented the APNSAs protocols by seeking and accepting information and advice from other sources, specifically outside the government.

McMaster`s tenure as APNSA strongly confirms the findings of previous studies of the APNSA that make the case that power and influence of an APNSA depends upon the personal relationship with the president. Donald Trump's presidency is a stark reminder that an APNSA power depends in large part on presidential preferences and authorization. The interpersonal dynamics between the NSC advisor and the president are crucial for the understanding of the APNSA role. What might seem reasonable behavior on the APNSAs part in insuring good order can mesh poorly with presidential expectations. If an APNSA does not enjoy the trust of the president, it will be impossible for the APNSA to serve in a powerful, influential capacity, no matter what role the APNSA seeks to play. Orderly and formal systems can perhaps increase the odds of sound policy choices, but they cannot guarantee them with a president whose decisionmaking style and use of channels of information and advice have been in marked contrast to his recent predecessors. The Trump presidency did not develop another model of the APNSA during McMaster's tenure. What emerged during the remainder of McMaster's tenure rather suggests disorder at times rather than a new order to replace the standard model. This evaluation of McMaster's tenure as APNSA further illustrates the continued need for research on the influence of presidential management style on the APNSA and U.S. foreign policy making.

\section{NOTES}

1. H. R. McMaster, Dereliction of Duty: Lyndon Johnson, Robert McNamara, the Joints Chief of Staff and the Lies that Led to Vietnam. (New York: HarperCollins, 1997).

2. Ivo H. Daalder and I. M. Destler, "Why National Security Advisor Is the Hardest Post for Trump to Fill: The Thankless Task of Advising a President Who Eschews Advice", Foreign Affairs, (September 11, 2019).

3. David E. Sanger and Steven Erlanger, "Unswayed by Allies, Trump Is Expected to Leave Iran Deal, Diplomats Say". (The New York Times, May 7, 2018).

4. Ivo H Daalder, and I. M. Destler, "How National Security Advisers See Their Role", in The Domestic Sources of American Foreign Policy: Insight and Evidence, (Ed. Eugene R. 
Wittkopf and James M. McCormick), (Rowman and Littlefield Publishers, New York, 2004: 171).

5. I. M. Destler, "National Security Advice to U.S. Presidents: Some Lessons from Thirty Years. World Politics 29 (2): 143-76 (1977); Kevin V. Mulcahy, "The Secretary of State and the National Security Advisor: Foreign Policymaking in the Carter and Reagan Administrations", Presidential Studies Quarterly 16 (Spring, 1986: 280-99); Joseph G. Bock, The White House Staff and the National Security Assistant: Friendship and Friction at the Water's Edge. (New York: Greenwood Press 1986); Zbigniew K. Brzezinski, “The NSC's Midlife Crisis." Foreign Policy 69 (Winter, 1987: 80-99); Richard A., Best, Jr. The National Security Council: An Organizational Assessment. (Huntington, NY: Nova Science Publishers 2001); Karl F., Inderfurth, and Loch K. Johnson, Fateful Decisions: Inside the National Security Council. (New York: Oxford University Press 2004); John P. Burke, "The Neutral/ Honest Broker role in Foreign Policy Decision Making: A Reassessment." Presidential Studies Quarterly 35: 2, (2005: 229-58); David. Rothkopf, Running the World: The Inside Story of the National Security Council and the Architects of American Power. (New York: Public Affairs 2005); Ivo H Daalder, and I. M. Destler, In the Shadow of the Oval Office: Profiles of the National Security Advisers and the Presidents They Served-From JFK to GeorgeW. Bush. (New York: Simon and Schuster 2009).

6. See e.g. Daalder and Destler, In the Shadow of the Oval Office; Burke, "The Neutral/ Honest Broker role".

7. E.g. Burke, "The Neutral/Honest Broker role"; John P. Burke. "The Institutional Presidency: Organizing and Managing the White House from FDR to Clinton", (Baltimore: Johns Hopkins University Press, 2000); Mulcahy, "The Secretary of State and the National Security Advisor.

8. Ivo H Daalder, and I. M. Destler, "How National Security Advisers See Their Role", p: 171).

9. Kevin V. Mulcahy and Harold F. Kendrick. "The National Security Adviser: A Presidential Perspective." In Executive Leadership in Anglo-American Systems, eds. Colin Campbell, S.J. and Margaret Jane Wyszomirski. (Pittsburgh: University of Pittsburgh Press, 1991).

10. Luis da Vinha. "Competition, Conflict, and Conformity: Foreign Policy Making in the First Year of the Trump."

11. Ivo Daalder and I. M. Destler "Can O'Brien Succeed as National Security Advisor? Maybe, but only if he realizes what his real job is-and if the president lets him do it", (Foreign Policy, September 20, 2019).

12. John Burke, 2017. "The Trump Transition, Early Presidency, and National Security Organization." Presidential Studies Quarterly 47: 571-96.

13. Kevin Marsh, "The Contemporary Presidency the Administrator as Outsider: James Jones as National Security Advisor." Presidential Studies Quarterly 42:4 (Dec. 2012: 827-842).

14. Robert K. Yin, Case Study research: Design and Methods, $2^{\text {nd }}$ ed. (London: Sage, 1994: 12).

15. Daalder and Destler "Can O'Brien Succeed as National Security Advisor?".

16. However, according to the idiosyncratic approach of presidential decision-making, the two main functions of the APNSA depend on the president's individual beliefs on management and preferred decision-making style. This approach argues that all 
presidents are unique actors and will devise very personal ways of making decisions. Decision-making processes must, therefore, be fit to the president's individual beliefs on management and preferred decision-making style. This issue is addressed in the conclusions. See: Dom Bonafede, 1976, "Carter staff is getting itchy to move to Washington;". National Journal 8 (44): 1542-47; William Newmann, (2004) “The Structures od National Security Decision Making: Leadership, Institutions,

17. Daalder and Destler "Can O'Brien Succeed as National Security Advisor?".

18. Kevin V Mulcahy and Harold F. Kendrick. 1991. "The National Security Adviser: A Presidential Perspective." In Executive Leadership in Anglo-American Systems, eds. Colin Campbell, S.J. and Margaret Jane Wyszomirski. (Pittsburgh: University of Pittsburgh Press, 1991).

19. Mulcahy and Kendrick, "The National Security Adviser: A Presidential Perspective", p: 264.

20. Mulcahy and Kendrick, "The National Security Adviser: A Presidential Perspective”, p: 264.

21. Marsh, "The Contemporary Presidency the Administrator as Outsider".

22. Mulcahy and Kendrick, "The National Security Adviser: A Presidential Perspective".

23. Mulcahy and Kendrick, "The National Security Adviser: A Presidential Perspective", p: 267.

24. Karl F. Inderfurth and Loch K. Johnson. Fateful Decisions: Inside the National Security Council. (New York: Oxford University Press, 2004: 274).

25. Secretaries of state and defense and other senior actors in the foreign policymaking community are excluded from private access to the president and will have additional restrictions imposed on their roles and influence by an APNSA acting as an agent. See Mulcahy and Kendrick, "The National Security Adviser: A Presidential Perspective", p: 270.

26. The figure is drawn from Crabb and Mulcahy's book 'American National Security: A Presidential Perspective.'

27. Marsh, "The Contemporary Presidency the Administrator as Outsider".

28. Bryan Bender, "Harward Turns Down Trump's National Security Adviser Offer," Politico, February 16, 2017, available at: https://www.politico.com/story/2017/02/ robert-harward-national-security-adviser-trump-balks-235120, (accessed February 22, 2020).

29. The full text of NSPM-4 is available at https://www.whitehouse.gov/presidentialactions/national-security-presidential-memorandum-4/ (accessed May 10, 2017).

30. John P. Burke, "Struggling with Standard Order: Challenges and Performance of the Trump National Security Council System", Presidential Studies Quarterly, 48: 4, December 2018: 640-666.

31. Bryan Bender, "Harward Turns Down Trump's National Security Adviser Offer," (Politico, 16 February 2017), https://www.politico.com/story/2017/02/robert-harwardnational-security-adviser-trump-balks-235120, (accessed February 22, 2020).

32. "HR McMaster weighs in on North Korea nuclear threat", Interview with H. R. McMaster, BBC News, December 19, 2017, Available at: https://www.bbc.com/news/av/ world-us-canada-42403260, (accessed May 10, 2017). 
33. See the NSPM-4: at https://www.whitehouse.gov/presidential-actions/nationalsecurity-presidential-memorandum- 4 /

34. Jenna McLaughlin. 2017. "The Guerilla Campaign Against McMaster is Alive and Well." (Foreign Policy, December 14), https://foreignpolicy.com/2017/12/14/theguerrilla-campaign-against-mcmaster-isalive-and-well/, (accessed January 3, 2018).

35. da Vinha. "Competition, Conflict, and Conformity".

36. Sharon LaFraniere, Maggie Haberman, and Peter Baker. "Jared Kushner's Vast Duties, and Visibility in the White House, Shrink," (New York Times, 25 November 2017).

37. Shane Harris, Carol D. Leonnig, Greg Jaffe, and Josh Downey. "Kushner's Overseas Contacts Raise Concerns as Foreign Officials Seek Leverage," (Washington Post, 27 February 2018).

38. Patrick Radden Keefe, 2018. "McMaster and Commander: Can a National Security Adviser Retain His Integrity If the President Has None?" (New Yorker, April 30: 41).

39. da Vinha. "Competition, Conflict, and Conformity".

40. Trump had, for example, mocked NATO as "obsolete" but the document described the alliance as "one of our greatest advantages." It also named Russia and China as malign influences, and declared that the Russians had used technology "to undermine the legitimacy of democracies." Such language was in sharp contrast with Trump's persistent avoidance of blaming the Kremlin for election interference. The national security strategy document is available at: https://www.whitehouse.gov/wp-content/ uploads/2017/12/NSS-Final-12-18-2017-0905.pdf

41. Patrick Radden Keefe, "McMaster and Commander: Can a national-security adviser retain his integrity if the President has none?", (The New Yorker, April 23, 2018).

42. Patrick Radden Keefe, "McMaster and Commander: Can a national-security adviser retain his integrity if the President has none?", The New Yorker, (April 23, 2018).

43. Daalder and Destler “Can O'Brien Succeed as National Security Advisor?

44. Wesley Morgan, "All the ways Mattis tried to contain Trump: The Defense secretary tried to steady the president without saying 'no,"' (Politico, December 20, 2018).

45. H. R. McMaster, Battlegrounds: the Fight to Defend the Free World, (HarperCollins: London, 2000: 193).

46. Susan Glasser, The Trump's White House War Within, (Politico Magazine, July 24, 2017).

47. Philip Rucker and Robert Costa. “'It's a hard problem': Inside Trump's Decision to Send More Troops to Afghanistan," (Washington Post, 21 August 2017).

48. James Kitfield, "Trump's Generals Are Trying to Save the World: Starting with the White House," Politico, August 4, 2017, available at: https://www.politico.com/ magazine/story/2017/08/04/donald-trump-generals-mattis-mcmaster-kellyflynn-215455.

49. McMaster, Battlegrounds, p: 156.

50. Susan Glasser, The Trump's White House War Within, Politico Magazine, July 24, 2017.

51. Patrick Radden Keefe, "McMaster and Commander: Can a national-security adviser retain his integrity if the President has none?", The New Yorker, April 23, 2018).

52. Keefe, "McMaster and Commander". 
53. Glasser, The Trump's White House War Within.

54. Glasser, The Trump's White House War Within.

55. Greg Jaffe and Philip Rucker, "A divide over U.S. Afghan strategy”, (Washington Post, August 5, 2017).

56. Brian Bennett and Noah Bierman, "Trump, who once backed withdrawal from Afghanistan, tries to sell the nation on deeper involvement", (Los Angeles Times, August 21, 2017).

57. McMaster, Battlegrounds, p: 214.

58. da Vinha. "Competition, Conflict, and Conformity.

59. Philip Rucker and Robert Costa. “'It's a hard problem': Inside Trump's Decision to Send More Troops to Afghanistan," Washington Post, 21 August 2017.

60. Trita Parsi, “Trump Hasn't Mastered the Art of Killing the Iran Deal." (Foreign Policy, November 11, 2016), http://foreignpolicy.com/2016/11/11/trump-hasnt-mastered-theart-of-killing-the-iran-deal/ (accessed August 8, 2020).

61. Paul Kerr, and Kenneth Katzman. 2018. Iran Nuclear Agreement and US Exit, (Washington, DC: Congressional Research Service, 2018).

62. Carol Morello, "Tillerson Compares Iran to North Korea, Vows Trump Administration Won't Pass the Buck," (Washington Post, 19 April 2017).

63. Karen DeYoung, "Trump Administration Plans to Certify Iranian Compliance with Nuclear Agreement," (Washington Post, 13 July 2017).

64. Stephen Hayes, and Michael Warren, "Getting to No: How the Trump Administration Decided to Decertify the Iran Nuclear Deal," (The Weekly Standard, October 16, 2017), http://www.weeklystandard.com/getting-to-no-how-the-trumpadministration-decided-to-decertify-the-iran-nuclear-deal/article/2009955 (accessed October 20, 2020).

65. McMaster, Battlegrounds, p: 295.

66. Anne Gearan, “'He Threw a Fit': Trump's Anger Over Iran Deal Forced Aides to Scramble for a Compromise," (Washington Post, 11 October 2017).

67. Gearan, “'He Threw a Fit”.

68. Peter Baker, "GOP Senators' Letter to Iran About Nuclear Deal Angers White House," (New York Times, March 9, 2015.

69. Thomas Gibbons-Neff, and David Sanger. "Mattis Contradicts Trump on Iran Deal Ahead of Crucial Deadline," (New York Times, October 3, 2017).

70. H. R. McMaster, Battlegrounds: the Fight to Defend the Free World, (HarperCollins: London, 2000: 296-97).

71. Eliana Johnson, "Trump Prepares to Wound Iran Deal-And Then Save It," (Politico, October 3 2017), https://www.politico.com/story/2017/10/03/trump-iran-nucleardeal-243427 (accessed September 10, 2017).

72. McMaster, Battlegrounds, p: 298.

73. Donald Trump, Remarks by President Trump on Iran Strategy, (The White House, October 13, 2017), https://www.whitehouse.gov/the-press-office/2017/10/13/remarkspresident-trump-iran-strategy (accessed October 1, 2020). 
74. Mark Landler, David Sanger, and Gardiner Harris. "Rewrite the Iran Deal? Europeans Offer a Different Solution: A New Chapter," (New York Times, 26 February 26, 2018).

75. McMaster, Battlegrounds, p: 299.

76. Susan B. Glasser, “How Jim Mattis Became Trump's 'Last Man Standing." (New Yorker, April 10, 2018), https://www.newyorker.com/news/letter-from-trumpswashington/how-jim-mattis-becametrumps-last-man-standing, (accessed April 23, 2020); Keefe, "McMaster and Commander.

77. Mark Landler, "Clashing Views on Iran Reflect a New Balance of Power in the Cabinet," (New York Times, 12 May 2018).

78. McMaster, Battlegrounds, p: 226ff.

79. Shortly after McMaster's ouster, however, President Trump announced on May 8, 2018 that his Administration would cease implementing U.S. commitments under the 2015 multilateral JCPOA with Iran and reimpose all U.S. sanctions that were in place prior to the JCPOA.

80. Mark Landler, “Trump Abandons Iran Nuclear Deal He Long Scorned”, The New York Times, May 8, 2018.

81. Peter Baker, “Will Trump Take 'Brutally Forthright' Advice from McMaster?" (New York Times, 25 February 2017).

82. Eliana Johnson, “Trump's Rebuke of McMaster Was Months in the Making," Politico, 20 February 2018, https://www.politico.com/story/2018/02/20/trump-mcmastertension-national-security-adviser-417110, (accessed February 20, 2018).

83. David A., Graham, 2018. “The President Who Doesn't Read.” (The Atlantic, January 5), https://www.theatlantic.com/politics/archive/2018/01/americas-first-post-textpresident/549794/, (accessed February 13, 2018).

84. Mark Landler and Maggie Haberman. "Trump Chooses Bolton for 3rd Security Adviser as Shake-Up Continues," (New York Times, 22 March 2018).

85. Johnson, “Trump's Rebuke of McMaster Was Months in the Making”.

86. Mark Perry, McMaster's Problem Isn't Trump. It's Mattis and Kelly: The "axis of adults" has been running foreign policy, but the national security advisor was quickly pushed to the kids' table, (Foreign Policy, March 7, 2018).

87. Trump used his campaign nickname for Hillary Clinton. See: Donald Trump, at: https://twitter.com/realDonaldTrump/status/965079126829871104, (accessed June 20, 2020).

88. Keefe, "McMaster and Commander.

89. William Newmann, 2004, "The Structures of National Security Decision Making: Leadership, Institutions, and Politics in the Carter, Reagan, and G. H. W. Bush Years." Presidential Studies Quarterly 34 (2): 272-305; Michael Link, 2000, “The Presidential Kaleidoscope: Advisory Networks in Action." In Robert Shapiro, Martha Kumar, and Lawrence Jacobs (Eds.) Presidential Power: Forging the Presidency for the Twentieth Century. New York, NY: Columbia University Press: 235-261.

90. Newmann, “The Structures of National Security Decision Making: Leadership, Institutions, and Politics in the Carter, Reagan, and G. H. W. Bush Years". 
91. Alexander George, 1981. Presidential Decisionmaking in Foreign Policy: The Effective Use of Information and Advice. Boulder, CO: Westview Press; Richard Johnson, 1974. Managing the White House: An Intimate Study of the Presidency. New York: Harper \& Row.

92. Fred Greenstein, I. 2000. The presidential difference. New York: The Free Press; Thomas Preston,. 2001. The president and his inner circle. New York: Columbia University Press: ..

93. da Vinha. "Competition, Conflict, and Conformity: Foreign Policy Making in the First Year of the Trump.

\section{ABSTRACTS}

This article examines the role of former National Security Adviser H. R. McMaster in the Trump administration. The article discusses four major roles performed by the APNSA - administrator, coordinator, counselor, agent - and asserts that McMaster served as a coordinator that failed to achieve a close relationship with the president. Probing the role and performance of President Trump's second APNSA underscores both the significance of a partly influential APNSA and apparent constraints in relation to what a president with a unconventional management style allowed him to do. Examining the importance of presidential management style on the role, power and influence of the APNSA will further our understanding of how, when, and under what conditions national security-level leaders make decisions.

\section{INDEX}

Keywords: National security adviser, H.M. McMaster, The Trump administration, the interagency process, Afghanistan, Iran.

\section{AUTHOR}

\section{MIKAEL BLOMDAHL}

Mikael Blomdahl is currently Assistant Professor in Political Science at Stockholm University and Linkoping University. He was awarded a PhD in 2009 for a thesis on the domestic political impact on U.S. foreign policy. His recent publications include articles in Comparative Strategy, Diplomacy and Statecraft and Armed Forces and Society. His primary research interests are Foreign Policy Analysis, U.S. foreign policy, humanitarian interventions, domestic and bureaucratic politics in foreign policy and re-examining the diversionary theory of war. 